\title{
Interdependence between public and private forage markets
}

\author{
ALAN R. COLLINS AND FREDERICK H. OBERMILLER
}

\begin{abstract}
Authors are former graduate research assistant and professor of Agricultural and Resource Economics at Oregon State University. Corvallis 97331. Collins is currently assistant professor in the Division of Resource Management, West Virginia University, Morgantown 26506.
\end{abstract}

\begin{abstract}
The concept of market interdependence is defined in this paper as the innuence that public market quantity allocations and pricing decisions have on observed quantity and price in private markets. The existence of market interdependence violates an implicit assumption of minimal public market influence when comparable private market prices are used to appraise resource value in public markets. Under interdependence, the comparable market approach becomes inappropriate for determining a fair market value in federal resource markets because government actions have the potential to affect observed prices in private markets. In this research, a case study of the Malheur National Wildlife Refuge (MNWR) is used to empirically estimate the existence of federal/private forage market interdependence. Statistical inferences from econometric modeling show strong support for interdependence between the MNWR grazing program and the alfalfa hay market in Harney County, Ore. The results of this case study can be applied to federal grazing lands managed by BLM and FS for grazing fee policy recommendations.
\end{abstract}

Key Words: fair market value, federal grazing, market value appraisal, Malheur National Wildlife Refuge

What should be the price of domestic livestock forage produced and consumed on federal lands? Public law provides an initial, deceptively simple, answer to that question. The Federal Land Policy and Management Act of 1976 requires that users of public land resources pay a "fair market value"(FMV) for these resources unless otherwise prescribed by statute. For federal forage resources, FMV was established by a pricing formula in the Public Rangelands Improvement (PRIA) Act of 1977.

With expiration of the PRIA formula in 1985, an appraisal of federal forage value was completed using a comparable market approach to determine FMV (Tittman and Brownell 1984). Under this approach, an operational definition of FMV is the price at which a private good or service provided by the federal government would be exchanged under competitive conditions. Thus, a comparable market approach extrapolates FMV for federal forage resources from observed private market prices of similar forage resources exchanged under competitive conditions.

Two major problems have been associated with the comparable market approach to establish livestock grazing fees on BLM and FS administered lands. They are: (1) dissimilar goods (forages) and use rights (terms and conditions of lease arrangements) provided by federal compared with private grazing leases; and (2) interdependence between federal and private forage markets. The first

\footnotetext{
The authors would like to thank Malheur National Wildlife Refuge personnel for their assistance, especially George Constantino and David Johnson. This manuscript was aided by the careful review and constructive criticisms of Dr. Walter Laybs and 2 anonymous reviewers.

West Virginia University, Agriculture Experiment Station Scientific Article \#2222.

Manuscript accepted 1 May 1991.
}

problem has been substantiated through documentation of higher, nonfee livestock grazing costs on BLM and FS lands (Torell, et al. 1986, Obermiller and Lambert 1984, Nielsen and Workman 1971, Roberts 1967). Ramifications of these cost differentials have been widely researched and discussed (Nielsen et al. 1985, USDI/ USDA 1977). These ramifications have influenced federal grazing fee recommendations to Congress (USDI/ USDA 1986).

Contrary to the abundant research on comparability problems, interdependence has been acknowledged in federal grazing fee literature but ignored as a research topic (Obermiller 1984). Although Quigley and Taylor (1983) identified market interdependence as the most damaging theoretical criticism of comparable market approaches for establishing of federal grazing fees, empirical effects of federal forage pricing and quantity allocations on private forage market prices and quantities have not been previously investigated. The objective of this research is to investigate the concept of market interdependence in a manner that can be applied to public land livestock grazing under BLM and FS management.

\section{What Does Forage Market Interdependence Imply?}

Research investigations relevant to federal/private market interdependence have been done for timber (Buongiorno et al. 1985, Clawson 1985, Adams 1974, Frazier 1967) and recreation (Reiling 1976). In this research, market interdependence is defined as the influence that quantity allocations and/or pricing of private goods provided by the public sector have on observed quantity and price in private markets. When market interdependence exists, changes in quantity or price of public sector goods give rise to price and quantity changes in private markets. For instance, federal/private forage market interdependence implies that substantial increases in federal grazing fees would change observed private forage market prices and quantities.

The existence of market interdependence is important in federal forage pricing for 2 reasons: (1) economic welfare implications of federal forage pricing; and (2) validity of assumptions underlying appraisal of federal forage market value with private forage market data. Theoretical welfare models of how market interdependence affects both first and second best pricing of federal forage are outlined in Collins (1988). For purposes of this paper, the importance of market interdependence is best illustrated in terms of its impact on appraisal of federal forage market values.

Appraisal is a defensible estimate of value given a set of underlying assumptions (Boyce and Kinnard 1984). However, the existence of market interdependence results in a violation of an implicit assumption of appraisal theory. That is, use of market value appraisal technique assumes that when an appraised resource is offered for exchange in the marketplace, it exerts minimal influence on observed exchange values from which market value is estimated. While modern appraisal techniques do not address 
violations of this implicit assumption (Boyce and Kinnard 1984, American Institute of Real Estate Appraisers 1983, Suter 1974, Murray 1969), an example of a violation is where publicly provided resources (like federal forage) affect exchange value in private markets which have been used to establish resource value by the public sector (FMV of federal forage). Because appraisal techniques generally assume zero influence, the existence of market interdependence would seriously compromise the use of comparable market approaches for public resource value appraisal.

The comparable market approach utilized by Tittman and Brownell made an assumption that zero influence exists between federal forage resources and private forage prices. However, the existence of federal/private forage market interdependence would violate this assumption. In the 11 Western states, the magnitude of BLM and FS managed lands is large enough to conceivably influence private forage markets. Nonfederal rangeland leasing over this entire region is about 42 million ha (Tittman and Brownell 1984) compared with 108 million ha of BLM and FS leased public rangeland (U.S. General Accounting Office 1988). Even with private rangelands generally being more productive, BLM and FS resources represent a substantial portion of forage leased in the western United States. At state and county levels, federal rangeland resources can represent even greater proportions. Examples are the state of Nevada and Harney County, Ore., where 82 and $73 \%$ of land are managed primarily by the BLM and FS (Fairfax and Yale 1987, Valde 1973).

If market interdependence does exist between federal forage resources and private forage markets, the quantity of forage provided by the federal government would influence observed private forage market quantities and prices. In this research, the connection between federal forage resources and private markets is postulated to stem from management adjustments taken by federal grazing permittee ranch operations in response to federal forage quantity changes. As 1 example, increased demand in the private grazing lease market would occur if federal grazing permittees responded to cutbacks in federal forage by replacing this seasonal forage supply with private grazing leases in an attempt to maintain herd size. In this case, federal forage quantity decisions would be transferred into private markets via an aggregate seasonal forage demand shift. For empirical estimation, the magnitude of interdependence influence depends upon how a majority of permittees respond to livestock grazing reductions on federal lands.

\section{The Existence of Forage Market Interdependence: A Case Study}

This research is a test for the existence of federal/private forage market interdependence. The livestock grazing program on the Malheur National Wildife Refuge (MNWR) and the alfalfa hay market in Harney County, Ore., are used as a case study example. The null hypothesis of this research is: market interdependence does not exist between the MNWR grazing program and the Harney County alfalfa hay market.

To empirically test for federal/private market interdependence, 3 conditions are necessary: (1) the federal and private markets must be separate markets; (2) coordinated price and/or quantity decisions must occur in the federal market; and (3) federal market size must be substantial when compared to the private market.

Under the first condition, buyers must not be able to move freely between federal and private markets for if they could, these markets could be aggregated into one. On the refuge, forage buyers have restricted access to this market based on permit requirements similar to those for BLM and FS grazing programs. With refuge and private forage markets being separate, refuge forage reductions can influence private forage markets by forcing permit holders to enter these markets to maintain herd size.

The second condition is one of monopoly power where quantity and price of each transaction are controlled by 1 party. On the MNWR, refuge administrators determine quantity and price for each permit. Coordinated actions among all permits are necessary to obtain a magnitude of change in the federal market that is needed to evaluate interdependence influences with quantitative models and statistical inferences. On the refuge, coordinated action took place when the majority of permits sustained forage quantity reductions which were not going to be restored in the future.

The third condition implies that an aggregation of permittee responses to federal market reductions would be of sufficient magnitude to affect a private market. For Harney County, the refuge provided slightly more forage $(127,000$ animal unit months (AUMs) based on cow/calf pairs) than alfalfa hay (approximately 112,000 AUMs) prior to permit reductions. Thus, this federal market was of substantial size relative to the private market prior to permit reductions.

\section{Case Study Area}

The MNWR was established in 1908 as a preserve and breeding ground for native birds (Fig. 1). Since the 1930s, livestock grazing

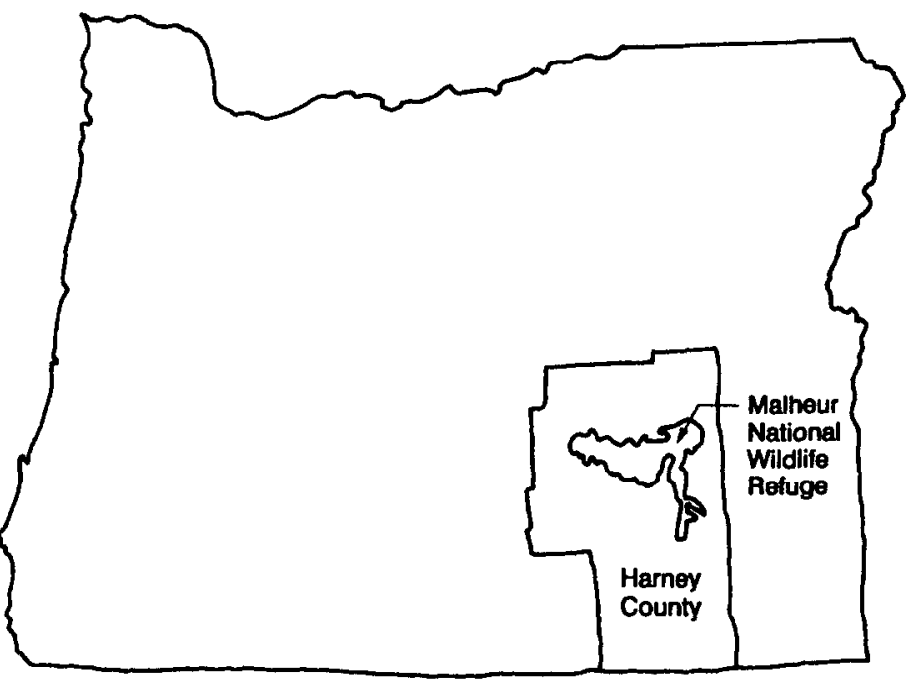

Fig. 1. Location of Malheur National Wildlife Refuge and Harney County, Oregon.

on the refuge has been an authorized management tool to remove excess forage growth from flood irrigated pastures. Most livestock grazing use occurs in the form of rake-bunch grazing where forage is harvested on irrigated pastures in late summer, bunched in piles, and grazed from October through January.

Permitted grazing use on the refuge varied between 110 and 120 thousand AUMs during the 1960s and early 1970s (Fig. 2). During this period, refuge forage provided a significant quantity of livestock forage in Harney County-between 25 and $30 \%$ of total November to March cattle forage requirements. Beginning in 1973, 2 events led to substantial reductions in livestock grazing on the refuge: (1) a change in MNWR management resulted in a deemphasis of grazing as a management tool; and (2) a predator control ban on U.S. Fish and Wildlife land created the need to increase ground nesting cover for birds such as mallards, gadwalls, cinnamon teal, and redheads.

Reductions were achieved by cutting permitted AUMs on existing permits and cancelling permits when ranch operations were sold or the owner passed away. Permitted use finally stabilized at about 40,000 AUMs in the mid-1980s (Fig. 2). When the policy of livestock forage reductions ended in 1981, permitted use had been reduced by roughly $70 \%$ from the 1973 level. This substantial 


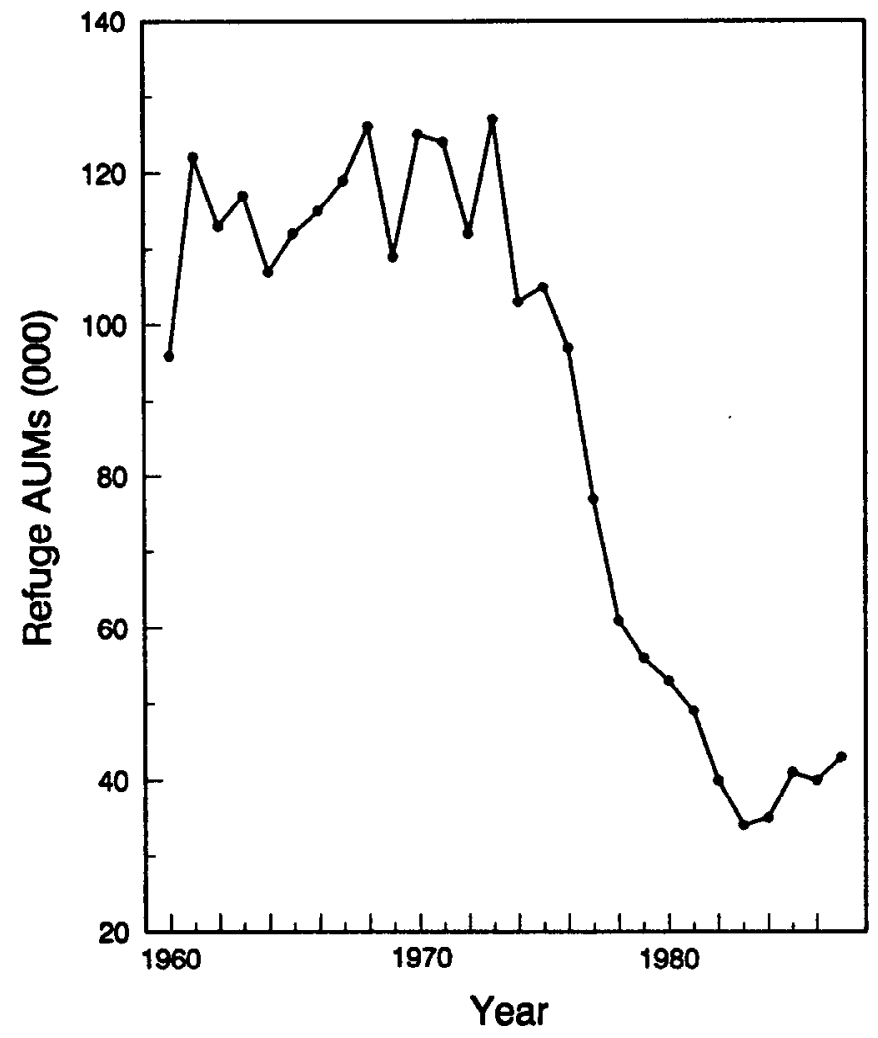

Fig. 2. Actual use AUMs from the Malheur National Wildlife Refuge Grazing and Hay Program, 1960-1987.

reduction in a federal forage market provides an ideal case study to test for market interdependence between federal and private forage markets.

\section{Methods}

Since the refuge provides late fall and early winter forage to permittee ranch operations, 2 private forage markets in Harney County are possible candidates for market interdependence: (1) forage land lease; and (2) hay. Based on a 1988 survey of refuge permittee responses to forage reductions, the hay market was identified as the primary private forage market affected by refuge grazing program changes.

This survey involved about half of the ranch operations using refuge forage during 1972. The results indicated that out of 25 ranch operators who responded to permit changes, 13 did so with hay purchases or hayland improvements to replace some or all of their refuge permit. Only 4 ranch operators leased additional forage land in response to permit changes. Specifically, for the alfalfa hay market, survey respondents developed over 400 ha of private hayland and purchased an additional 1,500 metric-tons annually. Based on Harney County alfalfa hay yields between 1974-79, these 1,500 metric-tons of hay purchases represent annual production equivalent to 240 ha of hayland. From the 25,000 AUM reduction experienced by survey participants as a group, an additional $640 \mathrm{ha}$ $(1,600$ acres $)$ of private alfalfa hayland were utilized to replace refuge forage.

To empirically estimate market interdependence, 2 influences of refuge forage reductions are hypothesized for the Harney County alfalfa hay market. These influences are: (1) increases in development of alfalfa hay acreage either by permittees to replace lost forage or by other hay producers in anticipation of hay prices increases; and (2) real price increases created by permittee hay purchases to replace reductions in refuge forage. Modeling of these influences draws from prior econometric research on alfalfa hay markets (Blake and Clevenger 1984, Myer and Yanagida 1984, Konyar and Knapp 1986).

To estimate the magnitude of federal/private forage market interdependence, a system of equations is formulated to link hay production and price influences:

$$
\begin{aligned}
& \mathrm{HAA}_{\mathrm{t}}=\mathrm{f}\left(\mathrm{EOAA}_{t} ; \Sigma_{\mathrm{n}=1}^{2} \mathrm{RF}_{\mathrm{t}-\mathrm{n}} ; \mathrm{D} 1\right) \text {, } \\
& H_{t}=f\left(H A_{t} ; T_{t}^{*} H A_{t} ; W_{t}\right) \text {, } \\
& H P_{t}=f\left(O R H P_{t} ; H_{t} ; C_{t}, R_{t-1}\right)
\end{aligned}
$$

where:

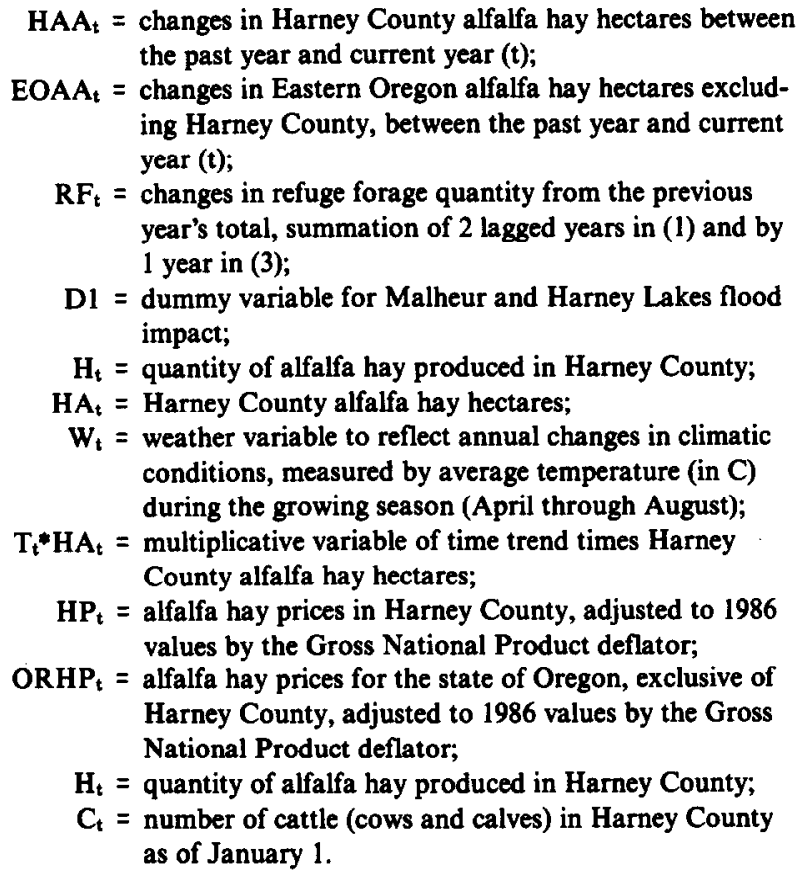

From the 2 influences of refuge forage reductions, RF variables are postulated to have negative coefficients in (1) and (3). The number of RF lags in each equation was estimated with an experimental approach to econometric modeling (Koutsoyiannis 1977). These lags are the result of 2 factors: (1) most permittee operations had multiple responses to refuge permit forage reductions which would tend to delay alfalfa hay purchases and/or alfalfa hay development (other responses included cutbacks and yearling numbers or a drawdown of existing hay stocks); and (2) alfalfa hayland development would be delayed by large capital requirements and climatic riskiness of this development in Harney County (Gomm 1979).

The existence of federal/private forage market interdependence is established by 2 statistical inferences from RF coefficients: (1) a significant difference from zero and (2) a significant structural change associated with the refuge reduction policy. Statistical significance for both tests would reject the null hypothesis and demonstrate that market interdependence exists between the MNWR grazing program and the Harney County alfalfa hay market.

RF variables are postulated to be negatively correlated with HAA and HP only after the 1973 implementation of a refuge policy to permanently reduce livestock forage. Refuge forage quantity changes prior to 1973 are hypothesized to have no influence on the alfalfa hay market due to the temporary nature of these quantity fluctuations.

To account for the hypothesized negative impact of RF variables after 1973, estimation of $R F$ coefficients is done with $R F$ variables in block-diagonal form (Johnston 1984). In this format, RF vari- 
ables are converted into 2 variables: (1) one with refuge forage quantity changes prior to 1974 and then zeroes afterwards $\left(\mathrm{RF}_{1960-}\right.$ 73); and (2) the other with zeroes to 1973 and refuge forage quantity changes starting in 1974 ( RF $\left._{1974-86}\right)$.

For the first statistical inference, a one-tailed Student's $t$-test is used to determine statistical differences from zero for $\mathbf{R F}_{1974-86}$. A structural change between $R F_{1960-73}$ and $R_{1974-86}$ coefficients is evaluated with a F-statistic based on a hypothesis that RF coefficients are equal in both time periods (Johnston 1984). Rejection of this hypothesis with a statistically significant $F$-statistic implies a substantial change in RF coefficients between periods.

As further evidence of market interdependence, the compatibility between survey results and econometric estimation is evaluated. From the permittee survey, an estimated 26 ha of additional private alfalfa hayland were developed per 1,000 AUMs of refuge forage reduction. Using this result, linear restriction testing is done on $\mathrm{RF}_{1974-86}$ coefficient in (1). A statistically insignificant $F$ statistic implies the 2 estimates are compatible.

For the other explanatory variables in (1), EOAA is hypothesized to be positively correlated with HAA. EOAA is used as a proxy variable to account for changing alfalfa hay price expectations and economic growth under an assumption of uniform price expectations and economic growth over all counties in eastern Oregon. D1 is used to explain the dramatic drop in Harney County alfalfa hay acreage due to flooding of Harney and Malheur Lakes. This flooding began in 1982 with hayland remaining submerged through 1988. Thus, D1 is a dummy variable with a value of 1 in 1983.

The independent variable HA in (2) is linked to the dependent variable in (1) by an identity of $\mathrm{HA}_{t}=\mathrm{HA}_{t-1}+\mathrm{HAA}_{t}$. In (2), HA is expected to be positively correlated with Harney County alfalfa hay production (H). Based on Oury (1965), the variable T*HA is used to reflect increasing technology (as measured by time trend) on per hectare yield of alfalfa hay. A weather variable accounts for annual temperature fluctuations because most hayland alfalfa is irrigated in Harney County.

In (3), $\mathrm{H}$ acts as an independent variable to explain alfalfa hay prices in Harney County (HP). Following Myer and Yanagida (1984), $\mathrm{H}$ is assumed to be predetermined in the short-run (i.e., hay production does not change in response to prices during the growing season). With this assumption, the $\mathrm{H}$ variable becomes a mea- sure of stock rather than demand and HP can be estimated as a function of $H$ (Heiden 1977). Following standard market theory, $H$ is postulated to have a negative influence on price. With alfalfa hay being a livestock production input, $C$ is used to account for shifts in final product demand and is expected to have a positive influence on price (Myer and Yanagida 1984). The ORHP variable represents a proxy variable for economic impacts on alfalfa hay prices outside of Harney County (such as energy price increases and agricultural price inflation).

Linear relationships are assumed among variables. An assumption of linearity is justified by the well established hypothesis testing techniques for regression coefficients in small samples (Judge et al. 1982). Initially, variable coefficients are estimated with ordinary least squares on each equation. If error terms are uncorrelated between equations, then this system of equations is a recursive system which is correctly estimated with ordinary least squares 1 equation at a time. Two tests, Breusch-Pagan Lagrangian Multiplier and likelihood ratio, are used to test the hypothesis that the error term covariance matrix is diagonal, i.e., no correlation between error terms.

Data from 1958 to 1986 are used in ordinary least squares estimation. Information on refuge forage quantities come from MNWR records. The Office of Economic Information at Oregon State University provided data on Harney County alfalfa hay market and cattle numbers, Eastern Oregon alfalfa hay acreages, and Oregon alfalfa hay prices.

\section{Results}

Ordinary least squares estimation of variable coefficients for each equation are shown in Table 1. Based on error terms from these equations, both Breusch-Pagan Lagrangian Multiplier test $\left(\chi_{3}^{2}=2.297\right)$ and the likelihood ratio test $\left(\chi_{3}^{2}=3.161\right)$ did not reject the null hypothesis of a diagonal error term covariance matrix. Thus, ordinary least squares estimation of each equation is appropriate.

Strong statistical support for market interdependence between the refuge grazing program and the Harney County alfalfa hay market is evident in Table $1 . \mathbf{R F}_{1974-86}$ coefficients are negative and statistically different from zero in both (1) and (3). Prior to the reduction policy, $\mathbf{R F}_{1960-73}$ coefficients are, as expected, not statistically different from zero.

For structural change, RF coefficients in (1) have a statistically

Table 1. Ordinary least squares estimation of regression coefficients for equations (1)-(3), 1960-1986.

\begin{tabular}{|c|c|c|c|c|c|}
\hline $\begin{array}{l}\text { Equation [1] } \\
\qquad \begin{aligned} & \text { HAA }=0.126 \\
&(0.105)^{1}\end{aligned}\end{array}$ & $\begin{array}{l}+0.023 \text { EOAA } \\
(0.022)\end{array}$ & $\begin{array}{l}+0.011 \mathrm{RF}_{1960-73} \\
(0.0105)\end{array}$ & $\begin{array}{l}-0.028 \mathrm{RF}_{1974-86} \\
(0.008)^{* *}\end{array}$ & $\begin{array}{r}-2.564 \mathrm{DI} \\
(0.468)^{* *}\end{array}$ & \\
\hline \multicolumn{3}{|c|}{$\begin{array}{l}\text { HAA: Harney Co. alfalfa hay hectare changes } \\
\text { EOAA: Eastern Oregon alfalfa hay hectare changes }\end{array}$} & \multicolumn{3}{|c|}{$\begin{array}{l}\text { RF: changes in refuge forage, two lags } \\
\text { D1: flood dummy variable }\end{array}$} \\
\hline $\begin{array}{l}\text { Equation [2] } \\
\qquad \begin{aligned} \mathbf{H}=9.605 \\
(14.681) \\
\mathrm{N}=27\end{aligned}\end{array}$ & $\begin{array}{l}+8.786 \mathrm{HA} \\
(1.239)^{* *} \\
\text { Adjusted }\end{array}$ & $\begin{array}{l}-0.011\left[\mathrm{~T}^{*} \mathrm{HA}\right] \\
(0.034) \\
978\end{array}$ & \multicolumn{3}{|l|}{$\begin{array}{l}-2.183 \mathrm{~W} \\
(0.913)^{*} \\
F_{3,23}=386.266\end{array}$} \\
\hline \multicolumn{3}{|c|}{$\begin{array}{l}\text { H: Harney Co. alfalfa hay production } \\
\text { HA: Harney Co. alfalfa hay hectares }\end{array}$} & \multicolumn{3}{|c|}{$\begin{array}{l}{\left[\mathrm{T}^{*} \mathrm{HA}\right] \text { : technology variable times } \mathrm{HA}} \\
\mathrm{W} \text { : average monthly temperature, April-August }\end{array}$} \\
\hline $\begin{array}{l}\text { Equation [3] } \\
\qquad \begin{array}{r}\text { HP }= \\
\text { 23.218 } \\
(15.337) \\
N=27\end{array}\end{array}$ & $\begin{array}{l}+0.863 \text { ORHP } \\
(0.087)^{* *} \\
\text { Adjusted }\end{array}$ & $\begin{array}{l}-0.217 \mathrm{H} \\
(0.073)^{* *} \\
857\end{array}$ & $\begin{array}{l}-0.046 \mathrm{C} \\
(0.178) \\
\mathrm{F}_{5,21}=32.107\end{array}$ & $\begin{array}{l}+0.056 \mathrm{RF}_{1960-73} \\
(0.160)\end{array}$ & $\begin{array}{l}-0.389 \mathrm{RF}_{1974-86} \\
(0.211)^{*}\end{array}$ \\
\hline $\begin{array}{l}\text { HP: Harney Co. } \\
\text { ORHP: Oregon }\end{array}$ & $\begin{array}{l}\text { fa hay prices } \\
\text { a hay prices }\end{array}$ & & $\begin{array}{l}\text { C: Harney } \\
\text { RF: changes }\end{array}$ & $\begin{array}{l}\text { attle numbers } \\
\text { fuge forage, one } \mathrm{L} \text {. }\end{array}$ & \\
\hline
\end{tabular}

IStandard error of estimated regression coefficient.

* Regression coefficient is statistically different from zero at $5 \%$ level, one-tail test for RF Find-86.

** Regression coefficient is statistically different from zero at $1 \%$ level, one-tail test for $R F_{1974-86}$ 
Table 2. Re-estimation of Regression Coefficients due to violations of Ordinary Least Square Assumptions.

\begin{tabular}{|c|c|c|c|}
\hline Equation [2] & \multicolumn{2}{|c|}{$\begin{array}{l}\text { Violation: First order Autocorrelation } \\
\text { Violation: Multicollinearity }\end{array}$} & $\begin{array}{l}\text { Correction: Cochrane-Orcutt Iterative Process, rho }=0.426 \\
\text { Correction: Drop }\left[T^{*} \text { HA] variable }\right.\end{array}$ \\
\hline \multirow[t]{3}{*}{$\begin{array}{l}\mathbf{H}=1.097 \\
(13.276)^{1}\end{array}$} & $\begin{array}{c}+8.428 \mathrm{HA} \\
(0.391)^{* *}\end{array}$ & $\begin{aligned}- & 1.340 \mathrm{~W} \\
& (0.846)\end{aligned}$ & \\
\hline & $\mathrm{N}=27$ & Adjusted $\mathrm{R}^{2}=0.981$ & $F_{2,24}=258.552$ \\
\hline & \multicolumn{2}{|c|}{$\begin{array}{l}\text { H: Harney Co. alfalfa hay production } \\
\text { HA: Harney Co. alfalfa hay hectares }\end{array}$} & $\begin{array}{l}\text { W: average monthly temperature, April-August } \\
T^{*} \text { HA: technology variable times HA }\end{array}$ \\
\hline Equation [3] & \multicolumn{2}{|c|}{ Violation: Multicollinearity } & Correction: Drop C variable \\
\hline \multirow[t]{3}{*}{$\begin{array}{c}\mathrm{HP}=19.769 \\
(7.381)^{*}\end{array}$} & $\begin{array}{l}+0.852 \text { ORHP } \\
\quad(0.075)\end{array}$ & $\begin{aligned}-0.228 \mathrm{H} \\
(0.055)^{* *}\end{aligned}$ & $\begin{array}{l}+0.059 \mathrm{RF}_{1960-73} \\
\quad(0.156)\end{array}$ \\
\hline & $N=27$ & Adjusted $R^{2}=0.863$ & $F_{4,22}=41.894$ \\
\hline & \multicolumn{2}{|c|}{$\begin{array}{l}\text { HP: Harney Co. alfalfa hay prices } \\
\text { ORHP: Oregon alfalfa hay prices }\end{array}$} & $\begin{array}{l}\text { RF: changes in refuge forage, one Lag } \\
\text { C: Harney Co. cattle numbers }\end{array}$ \\
\hline
\end{tabular}

'Standard error of estimated regression coefficient.

* Regression coefficient is statistically different from zero at $5 \%$ level, one-tail test for RF $1974-86$.

**Regression coefficient is statistically different from zero at $1 \%$ level, one-tail test for RF F $_{1974-86}$.

significant $F$-statistic $\left(F_{1,23}=6.970\right)$ at a $5 \%$ level. Based on this result, the estimated coefficient for $\mathrm{RF}_{1974-86}$ is statistically different from $R_{1960-73}$. Thus, both statistical inferences from RF coefficients in (1) reject the null hypothesis and are highly supportive of market interdependence.

In (3), a F-statistic for structural change in RF coefficients is not statistically significant $\left(F_{1,22}=0.957\right)$. Statistical inferences from RF coefficients in (3) do not reject the null hypothesis, but did show partial support for the refuge grazing program having a direct effect on prices in the Harney County alfalfa hay market based on the $R_{1974-86}$ coefficient being statistically different from zero.

$\mathrm{RF}_{1974-86}$ coefficient estimates in Table 1 imply that for each 1,000 AUM reduction in refuge forage: (a) Harney County alfalfa hay acreage increases by 56 ha (lagged over 2 years); and (b) real alfalfa hay prices increase by about $\$ 0.39$ per metric-ton (lagged 1 year). For example, (1) and (3) suggest that the Harney County alfalfa hay market experienced an increase of 1,120 ha of alfalfa hayland development and about an $\$ 8$ per metric-ton increase in real alfalfa hay price in 1978 based on an actual decrease of 20,000 AUMs of refuge forage between 1976 and 1977 (see Fig. 2).

Testing for a linear restriction on the $\mathbf{R F}_{1974-86}$ coefficient in (1) provided evidence that survey information and econometric estimation are compatible. With $\mathrm{RF}_{1974-86}$ equal to a minus 0.013 , a F-statistic for this restriction is: $F_{1,21}=3.676$. This F-statistic does not reject a null hypothesis of no difference $\left(F_{1,21,05}=4.32\right)$ between the 2 estimates of market interdependence influence on Harney County alfalfa hay acres.

When translated into a cumulative influence over the refuge reduction policy (from 1973 to 1981), Harney County alfalfa hay increases are estimated to be approximately 4,600 and 2,100 ha for econometric modeling and survey results, respectively. The total change in Harney County alfalfa hayland between 1973 to 1982 (prior to Malheur and Harney Lakes flooding) was 6,030 ha. Based on these estimates, the influence of refuge forage reductions accounted for about $1 / 3$ to $2 / 3$ of the total change in alfalfa hectares. While these estimates probably serve as lower and upper bounds for the true influence, they show that refuge forage reductions did have a substantial influence on hectares of Harney County alfalfa hay.

Coefficient estimates of 3 other explanatory variables in Table 1 are relevant to market interdependence. The EOAA coefficient in (1) is not statistically different from zero. Lack of statistical significance for EOAA shows that variations in HAA are explained by $\mathrm{RF}_{1974-86}$ rather than following alfalfa hayland development in the rest of eastern Oregon. Also, with statistical significance of coefficients for $H A$ in (2) and $H$ in (3), the influence of $R_{1974-86}$ on HAA can be indirectly linked to HP. This linkage is: reductions in refuge forage result in a lagged increase of alfalfa hay hectares in Harney County, which increases alfalfa hay production, thereby creating a negative impact on alfalfa hay price.

Due to the use of nonexperimental data, testing is done for violations of ordinary least squares assumptions. Violations are evaluated with: (1) an exact Durbin-Watson (D-W) test for positive autocorrelation (Judge et al. 1982); (2) regressions of squared residual terms $\left(\mathrm{e}^{2}\right)$ on independent and predicted dependent variables and plotting of $\mathrm{e}^{2}$ against $y$ for heteroskedasticity; (3) evidence for multicollinearity comes from a correlation matrix of variables and follows recommendations on condition indexes computed from eigenvalues in principal components analysis from Belsley et al. (1980).

There are no major problems with violations in equation (1). In (2), a Durbin-Watson statistic of 1.283 shows the presence of positive first-order autocorrelation of error terms. In addition, multicollinearity is a problem in (2) based on a condition index from principal components analysis of 183.7 , much larger than the problem level suggested by Johnston (1984). These violations are adjusted for by a Cochrane-Orcutt iterative procedure (Johnston 1984) and dropping of the T*HA variable because it is strongly correlated with HA (Table 2). For (3), multicollinearity is present among independent variables (condition index of 19). Regression coefficients in (3) are re-estimated by dropping the $\mathrm{C}$ variable which is correlated with $\mathrm{OR}$ and $\mathrm{H}$ (Table 2 ). With corrections for violations, the results of Table 2 do not change statistical inferences of market interdependence from Table 1.

\section{Discussion and Conclusions}

The need to conduct research on federal/private forage market interdependence is the result, in part, of comparable market approaches being used to appraise and price federal forage resources. All major federal grazing programs (BLM, FS, and U.S. Fish and Wildlife Service) presently use data from private forage markets to value public land livestock grazing and establish grazing fees.

It has been suggested that the comparable market approach is a constructive way of interpreting FMV only when the federal government's presence in the market is nominal (Gulley 1983-84). Comparable markets are constructive in this situation because competitive market forces are allowed to determine value without government influence. However, existence of market interdepend- 
ence shows that federal government presence cannot be considered nominal. In this research, statistical inferences from econometric modeling showed strong support for existence of market interdependence in a case study example of the Malheur National Wildlife Refuge grazing program and the Harney County alfalfa hay market.

Existence of market interdependence is evidence that an implicit appraisal assumption used in a comparable market approach has been violated. In the case study, by offering an appraised resource (refuge forage) for exchange in a federal market, a statistically significant influence was exerted on an exchange value (Harney County alfalfa hay prices) from which the appraised resource could be valued. Thus, a comparable market approach employing private alfalfa hay market data is not an appropriate valuation technique for FMV because federal government actions have influenced observed prices in this market.

Case study results suggest that market interdependence should be of concern in establishment of federal grazing fees policy. A federal/private market size ratio of 1.13 was present prior to the MNWR reduction policy. For BLM and FS grazing programs, there are 108 million ha of BLM/FS leases in the western U.S. compared to about 42 million ha of nonfederal leased grazing land. Even with greater forage productivity of private land, this size ratio for BLM/FS grazing programs and private land grazing leases strongly implies existence of market interdependence given that interdependence is found in Harney County with a federal/private ratio equal to 1.13 .

From a public policy standpoint, use of comparable market approaches in the presence of market interdependence would have particularly undesirable consequences when large changes are proposed in federal market quantity and/or price. In these instances, federal market changes would lead to substantial changes in private market prices. Thus, there would be a noticeable change in the same prices from which federal resource value was obtained via the comparable market approach.

Given existence of federal/private forage market interdependence, there is an alternative valuation technique for federal forage whose assumptions are not violated by market interdependence. Obermiller (1984) suggests utilizing a ranch operation budgeting approach to determine net returns to permit ownership. By using this technique, only data from federal forage markets are employed to value forage, thereby eliminating use of private forage market data.

\section{Literature Cited}

Adams, D.M. 1974. Forest products prices and national forest timber supply in the Douglas-fir region. Forest Sci. 20:243-259.

American Institute of Real Estate Appraisers. 1983. The appraisal of rural property. Chicago, Ill.

Belsley, D.A., E. Kuh, and R.E. Welsch. 1980. Regression diagnostics. John Wiley \& Sons, N.Y.

Blake, M.J., and T. Clevenger. 1984. A linked annual and monthly model for forecasting alfalfa hay prices. Western J. Agr. Econ. 9:195-199.

Boyce, B.B., and W.N. Kinnard. 1984. Appraising real property. Lexington Books for the Society of Real Estate Appraisers, Lexington, Mass.

Buongiorno, J., S.I. Bark, and L. Brannman. 1985. Volume offered and wood prices: A causality test for national forests. Forest Sci. 31:405-414.

Clawson, M. 1985. Did national forest stumpage sales accelerate inflation? J. Forestry. 83:748-752.

Collins, A.R. 1988. The public forage pricing implications of public/private market interdependence. Ph.D. Diss., Oregon State University, Corvallis.
Fairfax, S.K., and C.E. Yale. 1987. Federal lands: A guide to planning, management, and state revenues. Island Press, Washington, D.C.

Frazier, G.D. 1967. The relationship between forest service timber sales behavior and the structure of the California pine lumber industry. Ph.D. Diss., Yale University, New Haven. Conn.

Gomm, F.B. 1979. Climate and agriculture of Malheur-Harney Basin, Oregon. Oregon Agr. Exp. Sta. Spec. Rep. 530, Oregon State University, Corvallis.

Gully, D.A. 1983-84. The fair market value of federal coal. West Virginia Law Rev. 86:741-771.

Heiden, D. 1977. Price determination processes for agricultural sector models. Amer. J. Agr. Econ. 59:126-32.

Johnston, J. 1984. Econometric methods. 3rd Ed. McGraw-Hill, N.Y.

Judge, G.G., R.C. Hill, W.E. Grimths, H. Lutkepohl, and T.C. Lee. 1982. Introduction to the theory and practice of econometrics. John Wiley \& Sons, N.Y.

Konyar, K., and K. Knapp. 1986. Demand for alfalfa hay in California. Giannini Foundation Res. Rep. 333, Div. Agr. and Natural Resour., Univ. California, Berkeley.

Koutsoyiannis, A. 1977. Theory of econometrics. 2nd Ed. Harper \& Row Publ., Inc., Great Britain.

Murray, W.G. 1969. Farm appraisal and valuation. Iowa State Univ. Press, Ames.

Myer, G.L., and J.F. Yanagida. 1984. Combining annual econometric forecasts with quarterly ARIMA forecasts: A heuristic approach. Western J. Agr. Econ. 9:200-206.

Nielsen, D.B., E.B. Godfrey, and F.W. Obermiller. 1985. An evaluation of the Forest Service and Bureau of Land Management grazing appraisal report. Utah Agr. Exp. Sta. Res. Rep. 104, Utah State Univ., Logan .

Nielsen, D.B., and J.P. Workman. 1971. The importance of renewable grazing resources on federal lands in the 11 western states. Utah Agr. Exp. Sta. Cir. 155, Utah State Univ., Logan.

Obermiller, F.W. 1984. Economic theories, p. 27-46. In. J.H. Smits (ed.) Public Lands Committee, Nat. Cattlemen's Assoc., Washington, D.C.

Obermiller, F.W., and D.K. Lambert. 1984. Costs incurred by permittees in grazing livestock on public lands in various western states. Oregon State Univ. Ext. Serv., EM 8283 Corvallis, Ore.

Oury, B. 1965. Allowing for weather in crop production model building. J. Farm Econ. 47:270-283.

Quigley, T.K., and R.G. Taylor. 1983. Econometric estimation of range forage demand, p. 38-43. In: F.G. Wagstaff (ed.), Range Economics Symposium and Workshop, USDA, Forest Serv. Intermountain Forest and Range Exp. Sta. Gen. Tech. Rep.

Reiling, S.D. 1976. An economic analysis of policies, cost and returns for public and commercial campgrounds in the Oregon coast. Ph.D. Diss., Oregon State Univ., Corvallis.

Roberts, N.K. 1967. Discovering grazing values. J. Range Manage. 20:369-75.

Suter, R.C. 1974. The appraisal of farm real estate. The Interstate, Danville, Ill.

Tittman, P.B., and C.E. Brownell. 1984. Appraisal report and estimating fair market rental value of public rangelands in the western United States administered by USDA-Forest Service and USDI Bureau of Land Management. Report prepared for the BLM and FS, Washington, D.C.

Torell, L.A., E.B. Godfrey, and D.B. Nielsen. 1986. Forage utilization cost differentials in a ranch operation: A case study. J. Range Manage. 39:34-39.

USDI and USDA. 1986. Grazing fee review and evaluation final report 1979-85. Report of the Secretaries of Agriculture and the Interior, Washington, D.C.

USDI and USDA. 1977. Study of fees for grazing livestock on federal lands. Washington, D.C.

U.S. General Accounting Office. 1988. Rangeland management: More emphasis needed on declining and overstocked grazing allotments. Report to Congressional Requesters, Washington, D.C.

Valde, G. 1973. Harney County, Oregon resource atlas. OSU Ext. Serv., Extension Community Development Project. 